\title{
Development of Goods/Money Economy in Dry Mountainous Regions and the Occurrence of Regional Issues:
}

\author{
Irrigation Problems in Hussaini, a Village Located in the Valley of the Karakoram Range
}

\section{山岳乾燥地域における商品・貨幣経済の進展と地域課題の発生 \\ ーカラコラム山脈渓谷に立地するフセイ二村の灌溉用水問題一}

\section{Kazuo MIZUSHIMA* \\ 水嶋 一雄*}

Key words : irrigation problems, Wakhi people, Hussaini, Valley of the Karakoram Range, Northern Areas of Pakistan

キーワード : 灌溉用水問題，ワヒ民族，フセイニ村，カラコラム山脈渓谷，パキスタン北部地域

\section{要旨}

パキスタン北部地域ゴジャール地区に居住するワヒ民族のフセイニ村は, グルキン承河の形成したモレーン堆積物上に 立地し，麦類や豆類などを輪作する灌溉農業と羊や山羊を中心に移牧する牧畜を，伝統的生業にして自給自足の生活を維 持してきた。

ところが，1986年に開通したカラコラム・ハイウエー（KKH）は，ゴジャール地区に近代化と商品・貨幣経済を浸透さ せ，ワヒ民族の伝統的生業と自給自足の生活は一変することになった。このインパクトは，ゴジャール地区の多くの村々 で，麦類や豆類などの灌溉農業から，換金作物となるジャガイモ栽培の灌溉農業へと変化させたが，山岳乾燥地域のフセ イニ村に扔けるこの面積の拡大は，地域課題として灌溉用水問題を発生させることになった。

フセイニ村では, 従来からモレーン堆積物の下にある水河から溶け出す水を取水し， 5 本の用水路で村まで運び，村独 自の分配方法で農作物を灌溉してきた。もちろん, この栽培でも, 村は慢性的な用水不足に直面していたが, 自給自足の 生活では地域課題として浮上することはなかった。しかし, 市場販売を目的としたジャガイモ栽培面積の拡大と, 量や質 の維持には，安定した用水量は不可欠であったが，モレーン堆積物の下の水河から溶け出す用水量では，年ごとの気候条 件に影響を受けた水河の動向に左右されるため，極めて不安定で不足しがちであった。村はこの面積の拡大で深刻な灌溉 用水不足に陥った。

フセイニ村では，解決に試行錯誤を繰り返しながら，グルキン氷河末端から流れ出すグルキン川左岸から取水し，こ れを村まで運ぶという計画を立案した。しかし，この実現には，村まで約 $1 \mathrm{~km} の$ 距離をいかなる方法を採用すれば可能な のかが問題となったが，解決策に導水路となる鉄パイプを設置することを決定し，この購入費用をパキスタン政府に申請 した。2003年にこの申請が認可されたため，村は2004年にこの設置工事を実施した。設置の終了後，村は2005年に取水を 開始し2007年まで 3 本の鉄パイプで大量の用水を，3 本の既存の用水路に流し込むことに成功した。村はひとまず灌袮用 水不足を解決することになったが，固定できない取水口の不安定さ，地表に剥き出しの鉄パイプに落石による破損の危険 性, 漏水の著しい既存の用水路の利用など, 今後解決すべき課題も多く存在している。

\section{Overview}

The Wakhi, an ethnic minority, reside in the valleys of the Karakoram Range and Pamir Mountains spread across Pakistan, Afghanistan, Tajikistan and China ${ }^{1)}$. The villages of the Wakhi are situated in a dry mountainous area between 2,400 and 3,000 $\mathrm{m}$ a.s.l. with an annual precipitation of $350 \mathrm{~mm}$ or less. Facing a severe natural environment, these villages have maintained a self-sustained life relying

${ }^{*}$ College of Humanities and Sciences, Nihon University, Japan/日本大学文理学部 
on traditional living means of nomadic livestock production and irrigation agriculture with a rotation of wheat and beans.

In the 1990s, modernization and a goods/money economy penetrated the geographically remote, mountainous area where the Wakhi, who were still not living a civilised life at the time, were settled. This made the continuation of self-sustained life difficult for the Wakhi, and thus, they were forced to alter their way of life. In particular, in the Wakhi villages of Gojal district located in northern Pakistan, i.e., in the valley of the Karakoram Range, this change occurred rapidly due to the influx of people, goods, and capital derived from the opening of the Karakoram Highway (KKH) in 1986. The Wakhi villages responded in various ways, which varied according to the differences in location and natural environment.

The Hussaini, a Wakhi village in the Gojal district situated on moraine sediments created by the Gulkin glacier, has had a similar livelihood as the rest of the Wakhi villages, which was based on traditional means of living. However, the geographical environment of the Hussaini village and the presence of the Karakoram Highway have imposed a regional challenge on the Hussaini village, which is different from that faced by other Wakhi villages.

\section{Core issues}

The Hussaini village that stands on moraine deposition, unlike other Wakhi villages, has continued raising transhumance livestock and conducting irrigation agriculture by rotating wheat and bean crops, while accepting its geographic environment. Although the geographical environment of the Hussaini village did not allow for easy procurement of sufficient irrigation water even with traditional irrigation farming, water shortage was not much of a problem. Even while living under chronic water shortage conditions, the people of the Hussaini village have exerted their best efforts to acquire water, manage and repair ditches, and distribute irrigation water.

However, with the development of a goods/money economy, the Hussaini village, as other Wakhi villages, introduced potato cultivation and sale as a cash crop in order to obtain monetary income in the transition to a lifestyle that requires such income. Notably, the Hussaini village did not have the facilities to receive tourists and thus were not able to obtain income from tourism and were left to depend on potato cultivation. Ample irrigation water is a requisite for sustaining the volume and quality of cash crops in the dry mountainous areas since it directly impacts the stable income; however, the problem of chronic water shortage in the Hussaini village posed a serious challenge for the expansion of the potato cropland.

\section{Purpose of study}

The Hussaini village, in a drastic alteration of self-sustained life, altered the irrigation farming from wheat and bean crop rotation to one that relied on the cultivation of cash crop potatoes as a means of obtaining monetary income. However, this alteration resulted in a chronic irrigation water shortage in the Hussaini village, and the village was burdened with a critical problem. In recent years, many reports in relation to the Wakhi have been accumulated (Kreutzmann, 1996; Ochiai and Mizushima, 2004; Mizushima, 2006, 2008, 2009). This report clarifies the contributing factors for the shortage of irrigation water in the vast alteration of irrigation farming in the Hussaini village and the method that was adopted for resolving this issue. 


\section{IV . Location and overview of the Gojal district in northern Pakistan}

The Gojal district is located in the far northern part of Pakistan, as shown in Fig. 1, bordering China on the north and Afghanistan on the northwest. The Gojal district is on the northern side of Gilgit, a core city in northern Pakistan.

The Hunza River, a tributary of the Indus River, formed the valley of the Karakoram Range that runs through the centre of the district.

The valleys of the Karakoram Range exist among a series of mountains with an elevation of 5,000 to $6,000 \mathrm{~m}$. The dry mountainous region receives an annual precipitation of $350 \mathrm{~mm}$ or less, with a summertime temperature of over $30^{\circ} \mathrm{C}$ and an average humidity of $30 \%$, and a wintertime temperature of -10 to $-15^{\circ} \mathrm{C}$ and an average humidity of 60\% (Waragai, 2008). The valleys in the Karakoram Range have large mountain glaciers, as can be observed in Fig. 2, and the river at the end of the glacier receives a massive inflow from the glacier. The Wakhi draws this water to the village through an irrigation channel and has developed the irrigation farming of wheat and bean crops, which sustained the village.

The KKH was opened in 1986 along the Hunza River, running through many villages in central Gojal district and through Sost, a city with a Pakistani immigration office and customs, and continues on to the Xinjiang Uyghur Autonomous Region from the Khunjerab Pass that borders China. The opening of this highway contributed to advancing modernization in the northern region of Pakistan, particularly for developing the goods/ money economy. Notably, the wild but rich mountain view has facilitated tourism development, and consequently, hotels were built in villages in response

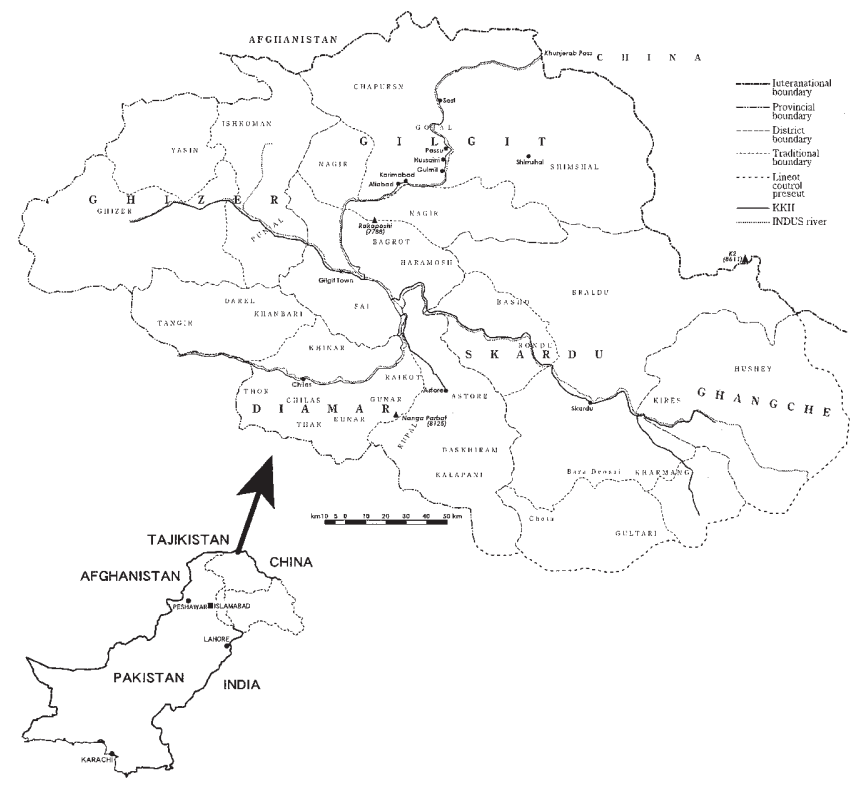

Fig. 1. Gojal district, the Northern Area of Pakistan.

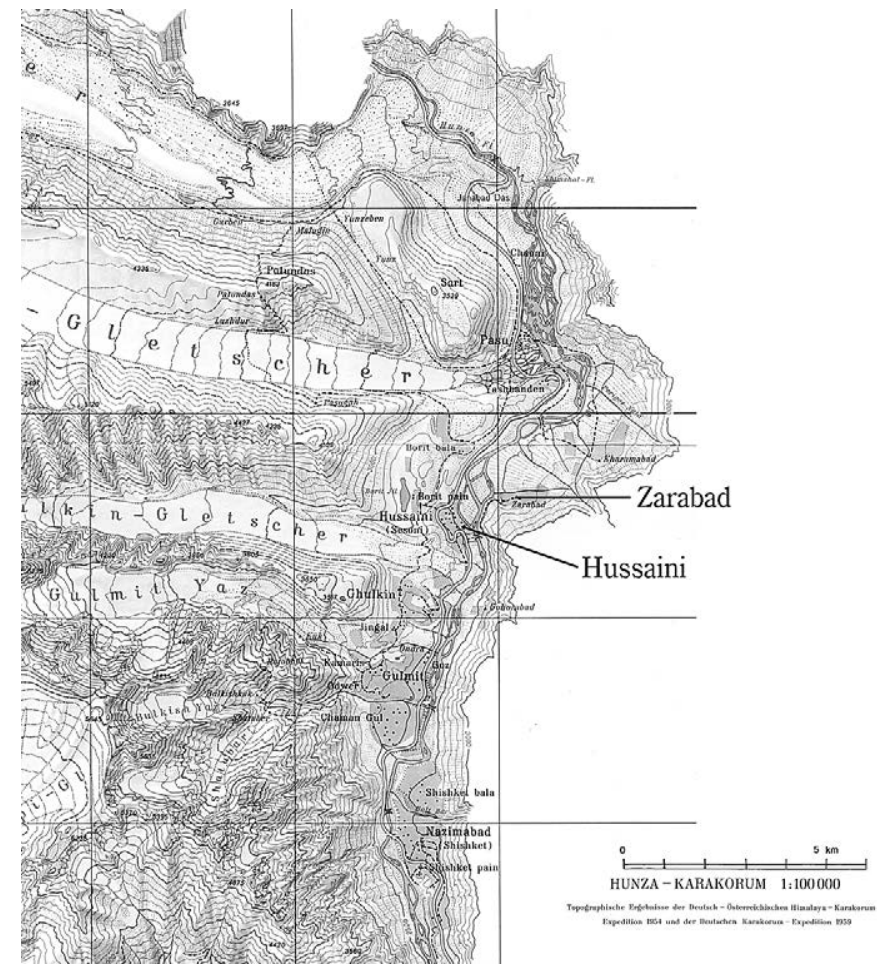

Fig. 2. Natural environment of Gojal district. 
to the inflow of tourists. However, simultaneously, massive amounts of goods flowed in from China, drastically changing the lifestyle of people in the region and their form of agriculture.

\section{Irrigation system of the Hussaini village and the irrigation water shortage \\ 1. Overview of location and region}

The Hussaini village is located at the tip of the Gulkin glacier, as shown in Fig. 2, and stands on the eastern slope of the glacial moraine deposition. On the east side of the Hussaini village, at an altitude of 2,400 m, is the Hunza River, which forms a terrace cliff of $20 \mathrm{~m}$ against the village. The Hussaini village lies in a dry mountainous region that is climatologically similar to the Gojal district, and has cropland in two areas, in the main Hussaini village (hereafter Hussaini village) and in Zarabad on the other side of the Hunza River. Villagers reside only in the Hussaini village. The KKH runs through the Hussaini village, offering good transportation access and thus subjecting it to a strong influence of the goods/money economy. Seventy-nine farm households with a total of 565 people (2002) live in the Hussaini village, and all are farmers who own cropland both in the Hussaini village and Zarabad. Similar to the other villages in the Gojal district, the Hussaini village was developed on the foundation of the traditional livelihood of irrigation agriculture and raising livestock; however, currently, all cropland is dedicated to potato farming, and traditional apricot and mulberry trees are grown around the houses, in addition to the apple trees that have been cultivated in recent years. Livestock, specifically goats and sheep, are raised in transhumance style. During the summer, they are kept on grazing land on the right bank of the Batura glacier, $10 \mathrm{~km}$ away from the village. During the winter, the animals are kept in livestock barns adjacent to houses in the village.

In the Hussaini village, through which the KKH passes, while gaining income from the sale of potatoes, a lifestyle that demands monetary income has become the norm (purchase of potato sets, chemical fertilisers, cooking oil and flour, educational fees, payment for electricity, etc.). Of course, the income from the sale of potatoes is not sufficient to sustain such daily life; thus, many villagers, particularly the younger ones, are engaged in other industries outside the village and some even outside the country to earn income.

\section{Present condition of potato cultivation}

The Hussaini village introduced potato cultivation based on the guidance from the Aga Khan Rural Support Programme (AKRSP) and expanded their potato farm along with the development of the goods/money economy from the $1990 \mathrm{~s}^{2}$. As a result, cropland in the Hussaini village is almost completely dedicated to potato cultivation, as shown in Photo 1 . According to the field survey of the Hussaini conducted in 2005, the total area of potato farms

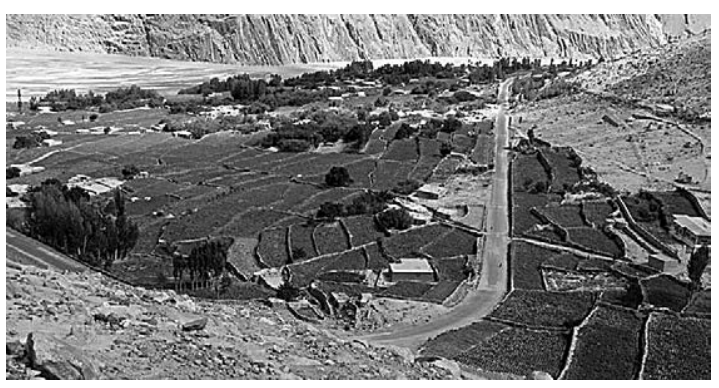

Photo 1. Potato cultivation land of the Hussaini village (Photo: 31 August 2007). for 80 farming households was 593 kanal (1 kanal equals approximately 5 acres), and the number of farm households by size of cultivated land is as illustrated in Table $1^{3)}$. Most farmers had a farmland of 4-6 kanal (31 households), followed by 18 households each for 7-9 kanal and 10-12 kanal. The largest area of farmland owned by one 
household was $20 \mathrm{kanal}$, and the average farmland area per household was 7.4 kanal. Yield per kanal is not exactly known, but is estimated to be $400-500 \mathrm{~kg}$ per kanal, which is a high yield per area considering the regional conditions. However, the soil of the cropland founded on moraine deposits is far from fertile; thus, the farmers scatter manure from the livestock barn before the spring ploughing. However, this is insufficient to retain fertility in the soil. Therefore, all farmers infuse chemical fertilisers (nitrogen fertiliser) that cost Rs. 800 per $50 \mathrm{~kg}$ (1 bag). In addition, because the potato set also influences the yield, new potato sets are purchased for cultivation from a nursery company every two to three years ${ }^{4)}$. Most of the harvested potatoes are sold to buyers in a 100-kg bag after size selection for Rs. 1,000 each (2005). A part of the harvest is preserved for personal consumption; thus, the sale amount of each farming family depends on the number of members in the family.

The Hussaini village has introduced cash crop potato farming and has expanded its farmland to obtain monetary income; however, in consideration of necessary expenses such as purchase cost of potato sets and chemical fertilisers for increasing yield and sales volume, the income is not necessarily large. Potato cultivation targeting market sale requires a constantly stable quantity and quality, and in order to satisfy both demands, it was crucial for the Hussaini village, located in the dry mountainous area, to have a steady supply of water even more than potato sets or chemical fertilisers.

Table 1. The number of farm households by size of cultivated land in the Hussaini village (2005).

\begin{tabular}{ccccccc} 
Total farm households & $1-3$ kanal & $4-6$ kanal & $7-9$ kanal & $10-12$ kanal & $13-15$ kanal & 16 -kanal \\
80 & 8 & 31 & 18 & 18 & 3 & 2 \\
$(100.0 \%)$ & $(10.0 \%)$ & $(38.8 \%)$ & $(22.5 \%)$ & $(22.5 \%)$ & $(3.7 \%)$ & $(2.5 \%)$ \\
\hline
\end{tabular}

\section{Traditional irrigation system}

In the Gojal district, located in the dry mountainous region, the yield was sustained by rotating wheat and bean crops, and to secure that yield, a steady supply of irrigation water was needed. Many Wakhi villages developed agriculture at locations where the villagers could draw ample irrigation water from glacier-based rivers and thus develop the villages.

On the other hand, the Hussaini village without a river flowing from the glacier had a different method of drawing irrigation water. The Hussaini village, standing on the moraine

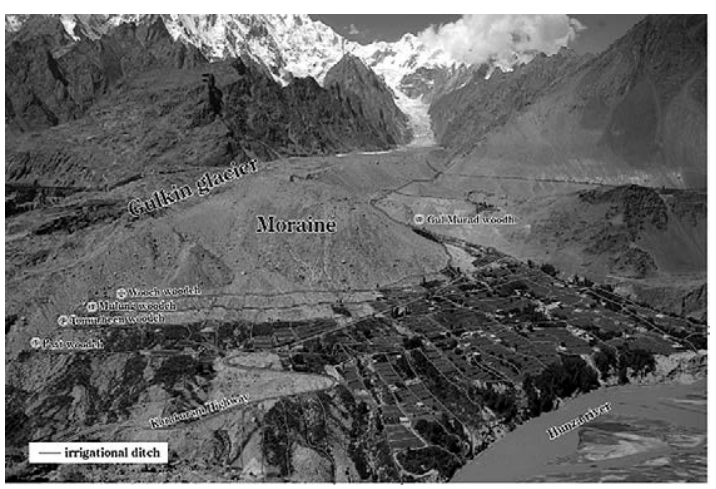

Fig. 3. Five irrigation canals of the Hussaini village (Photo: 31 August 2007). deposition at the end of Gulkin glacier, drew irrigation water to the village from the glacier from under the moraine deposition using five ditches (1. Gul Murad woodh, 2. Wooch woodh, 3. Mulung woodh, 4. Tomurbeen woodh, 5. Past woodh), as shown in Fig. 3. The five traditional ditches were built over a long period of time with the efforts and wisdom of the villagers. The water drawn from the ditches was also used as drinking water, making it valuable for the survival of the villagers.

However, the amount of irrigation water available was unstable. One factor was that the water that melted from under the moraine deposits was influenced by the weather conditions, and the point 
of water intake moved or broke depending on glacier conditions. Moreover, a simple ditch built on moraine deposits faced the possibility of leaking and collapsing while drawing the water all the way to the village. Although the amount of water carried by the five irrigation ditches may be unstable, since the village had no particular custom regarding water rights, in a village with a strong sense of community bonding, the water is evenly distributed to all farmers or cropland. Therefore, the Hussaini village has sustained irrigation farming of wheat and bean crops by establishing a villagespecific distribution method, as shown in Table 2. Furthermore, since the procurement of water was a vital issue for the village, as the most important rule, the management and repair of the water intake points and ditches were undertaken by the village as a whole in terms of labour and funds. As such, the Hussaini village has faced a problem of unstable water supply, but this problem has not surfaced in traditional irrigation farming.

Table 2. Methods to distribute the irrigation water in the fields (case of Gul Murad woodh).

\begin{tabular}{cccc}
\hline & First irrigation & Second irrigation & Third irrigation \\
\hline A group & $1^{\text {st }}$ April & $5^{\text {th }}$ April & $9^{\text {th }}$ April \\
B group & $2^{\text {nd }}$ April & $6^{\text {th }}$ April & $10^{\text {th }}$ April \\
C group & $3^{\text {rd }}$ April & $7^{\text {th }}$ April & $11^{\text {th }}$ April \\
D group & $4^{\text {th }}$ April & $8^{\text {th }}$ April & $12^{\text {th }}$ April \\
\hline
\end{tabular}

Note: The 32 farm households are classified into four groups $(A-D)$. Then, the irrigation water is distributed to each group on a daily rotational basis.

\section{The irrigation water problem}

In 1986, the KKH was opened to foreigners, and thus, many foreigners came to the Gojal district, furnishing the district with a free exchange of people, goods, and capital. This impacted the pattern of a self-sustained life and contributed to the alteration of the traditional agricultural style of cultivating wheat and bean crops. The villagers responded to the emergence of a society that required monetary income by introducing potato farming to produce a cash crop as a source of income and the expansion of such agriculture.

The Hussaini village experienced a similar change, but it differed from many other villages in the Gojal district in that it had a chronic irrigation water problem due to its geographical environment. As mentioned previously, the irrigation water shortage was already known from the unstable supply of water from the glacier that runs from under the moraine deposits as shown in Photo 2, and the conditions of traditional ditches as shown in Photo 3. The village responded to this problem with the management and repair of water intake points and ditches and by trying various measures including the construction of unique furrows in the potato fields as shown in Fig. 4, without

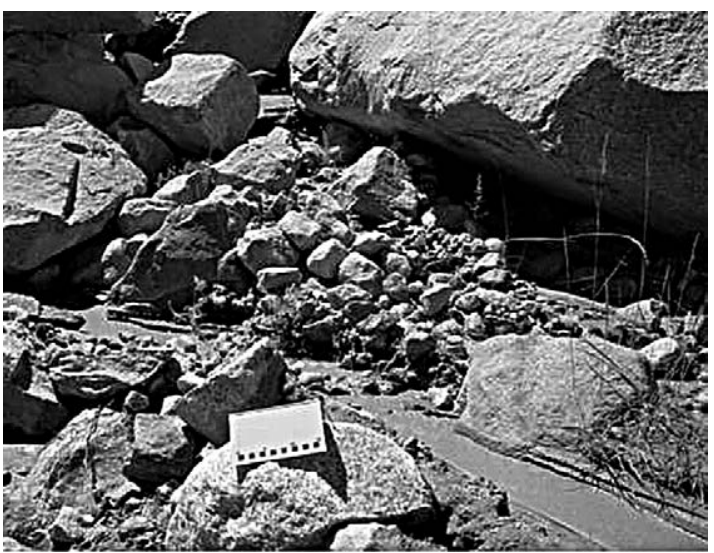

Photo 2. Original water under the moraine of the Gulkin glacier (4. Tomurbeen woodh). (Photo: 31 August 2007) 
finding a fundamental solution to the problem. Despite the fact that water shortage has a critically damaging effect on the quantity and quality of potatoes in a dry mountainous region, the Hussaini village expanded the area for potato farming without resolving this issue, and thus, this shortage manifested itself, establishing the problem of irrigation water supply.

\section{Resolution of irrigation water problem}

In the drastic transition from a traditional livelihood-based self-sustained life to a lifestyle that needs monetary income, the villagers were forced to consider a means of obtaining stable monetary income. Some villagers were able to gain income by engaging in various jobs outside the village or by working in another country, but most farmers in the Hussaini village secured income by expanding their potato farm and increasing their yield and sales volume. This can be understood from the fact that all cropland in the Hussaini village had been converted to potato fields. However, as previously noted, maintaining yield and quality of the potatoes and raising the sale price required a stable supply of irrigation water, but the conventional method had its limits.

The Hussaini village repeated trials and errors to solve the problem of irrigation water shortage that emerged from expanding the potato fields. One solution was that the Hussaini village decided to draw water from the left bank of the Gulkin River flowing from the end of the Gulkin glacier-a water-drawing method that was previously inconceivable. The next problem was transporting the water over a distance of

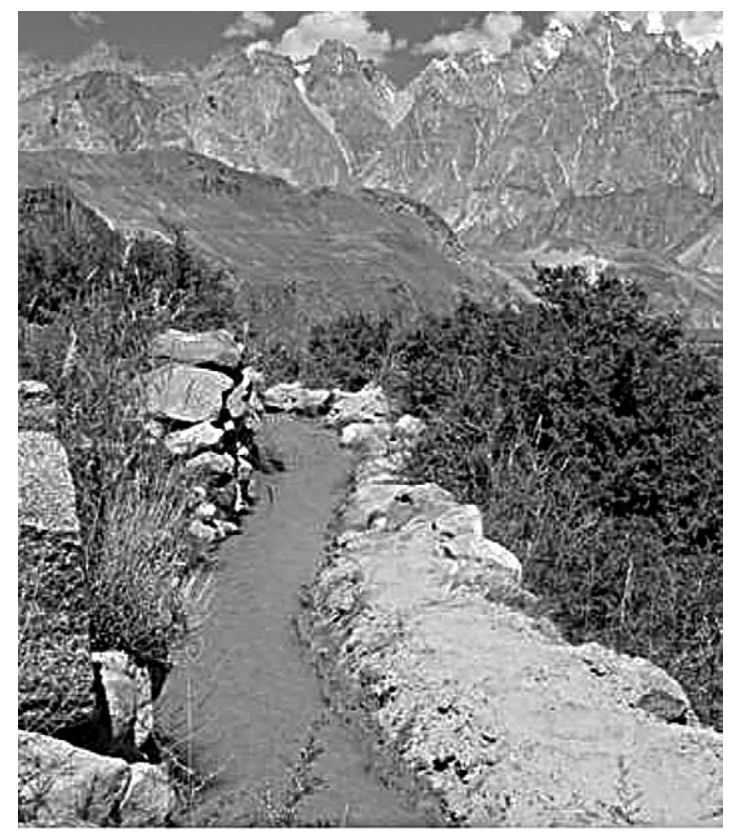

Photo 3. Tomurbeen woodh of the traditional ditch (Photo: 31 August 2007).

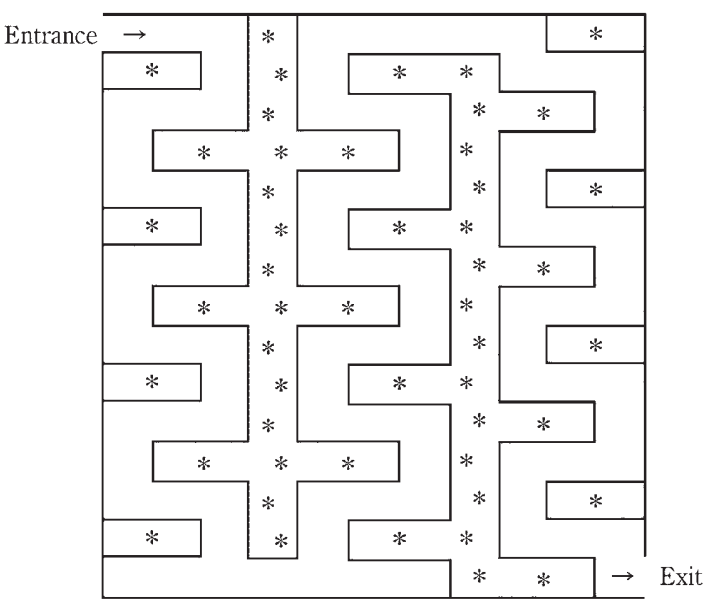

Fig. 4. Construction of unique furrows for potato cultivation (A schematic depiction). *: potato approximately $1 \mathrm{~km}$ to the existing five irrigation ditches from the water intake point. The adopted method involved installing steel pipes for an aqueduct. Hence, in 2003, the Hussaini village applied for subsidy to the Pakistani government for purchasing the steel pipes. This application was approved, and the installation of the aqueduct steel pipes began from 2004. The three steel pipes were laid down at the end of the glacier as shown in Photo 4. Use of the aqueduct began in April 2005, a year after its installation. In 2005, water drawn with the steel pipes poured into the Mulung woodh ditch as shown in Photo 5. In April 2006, the Tomurbeen woodh ditch received water from the pipes as shown in 
Photo 6, and in April 2007, the Past woodh ditch received water as shown in Photo 7.

The long-sought solution for the irrigation water problem of the Hussaini village was finally found; however, some issues were yet to be resolved. For instance, the water comprises a simple construction of rocks stacked together as shown in Photo 8 and may easily break. In addition, the flow direction of the Gulkin River changes with the movement of the glacier, making the water intake point unstable. Silt and fine sand contained in the glacier water accumulates at the water intake point, which also hinders the sufficient procurement of the required water amount. On the other hand, an exposed steel pipe installed without care would be constantly at risk from damage due to falling rocks and the climate condition with extreme temperature differences. Furthermore, the great amount of water pouring in from the steel pipes is carried to the village by the existing irrigation ditches, but these ditches have much leakage, adding to the risk of the walls of the ditches collapsing easily and thus blocking the waterway.

Although the village still has to resolve many issues as mentioned above, the village finally obtained a stable supply of water. At the Hussaini village, rules regarding water supply protection have been established; farmers are obligated to pay according to the cropland area they benefit from (Rs. $140 / \mathrm{kanal}$ ), and using this fund, two farmers are assigned throughout the year to work exclusively on managing and repairing the water intake point, steel pipes, and irrigation ditches.

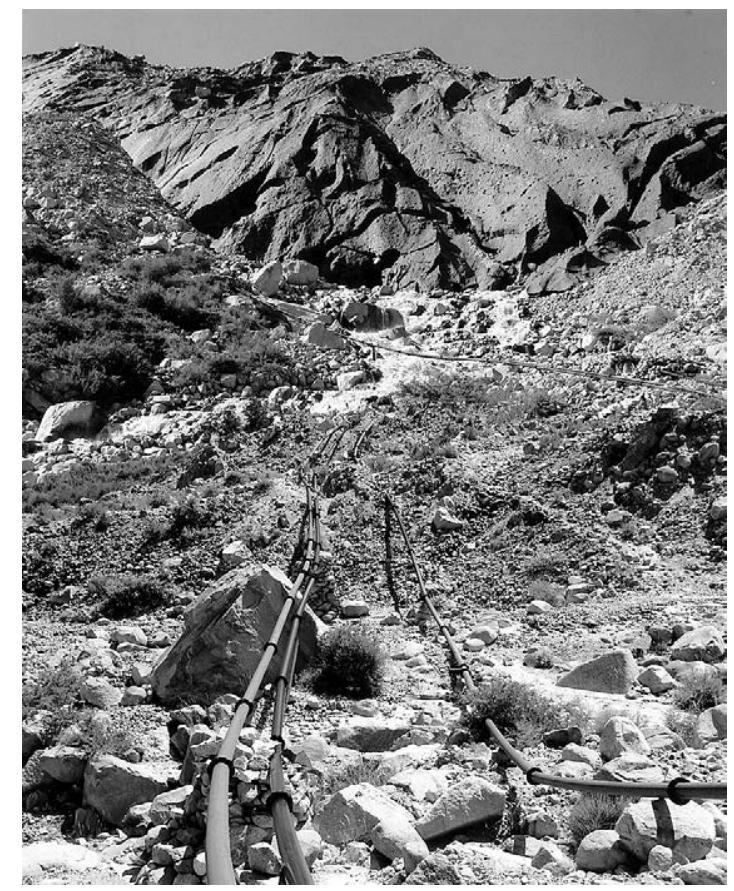

Photo 4. Irrigation from the Gulkin glacier using steel pipes (Photo: 31 August 2007).

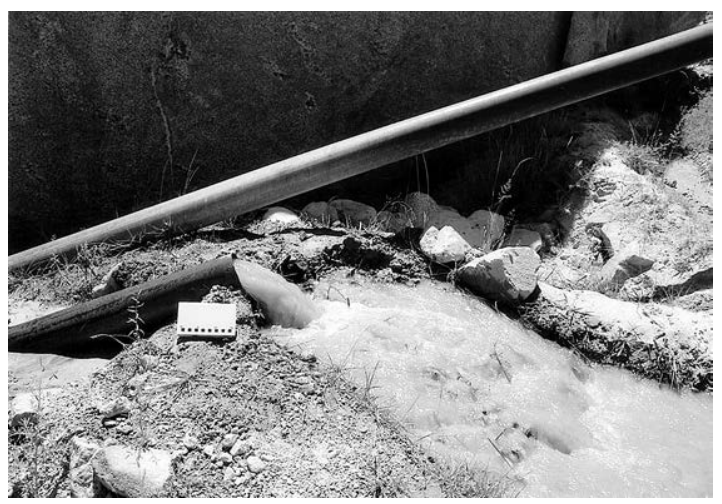

Photo 5. Water of Mulung woodh, which was carried from the Gulkin glacier (Photo: 31 August 2007).

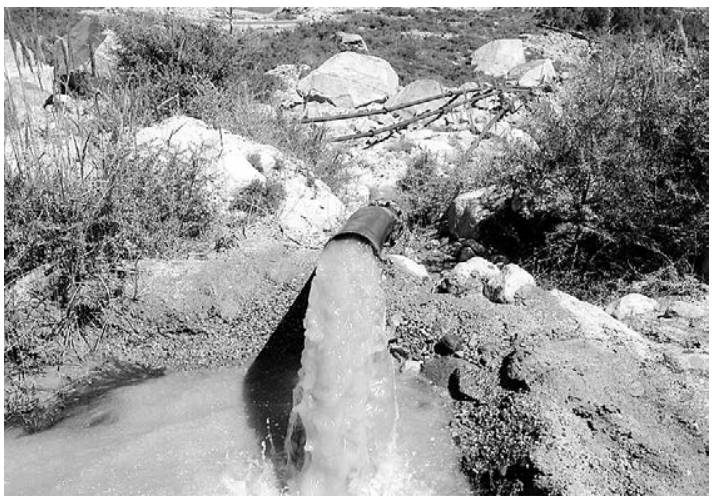

Photo 6. Water of Tomurbeen woodh, which was carried from the Gulkin glacier (Photo: 31 August 2007) 


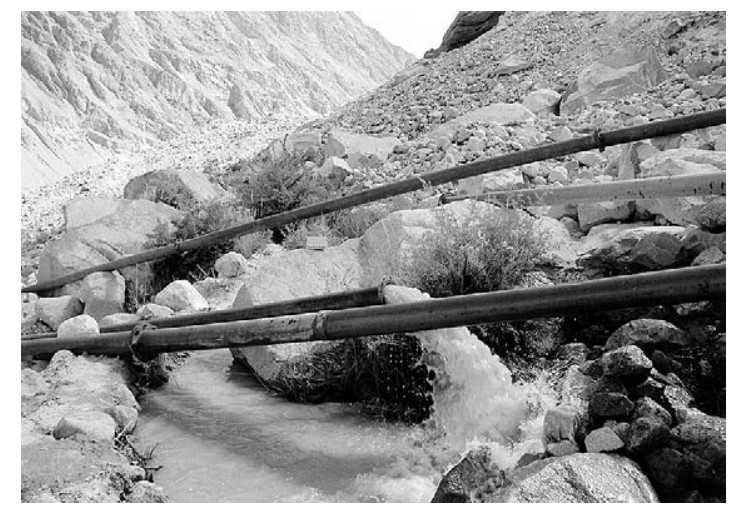

Photo 7. Water of Past woodh, which was carried from the Gulkin glacier (Photo: 31 August 2007).

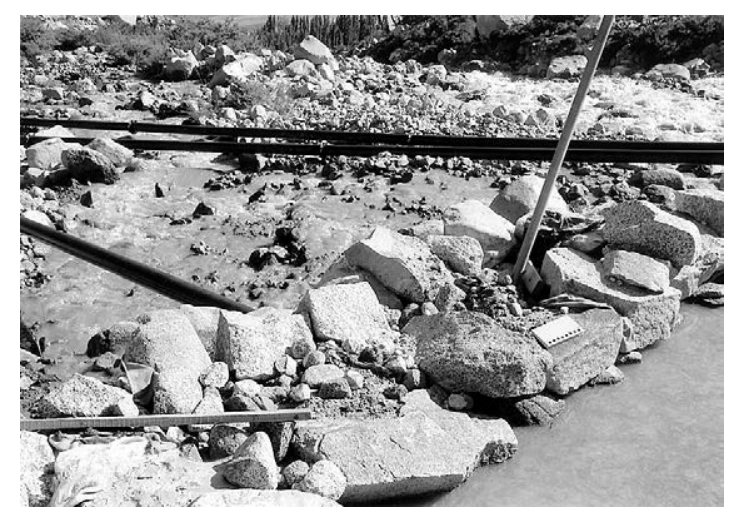

Photo 8. A sluice gate of the Gulkin river (Photo: 31 August 2007).

\section{Discussion}

The Gojal district's dry mountain environment does not allow the possibility of ignoring irrigation water, even for upland field crops. A stable yield of traditional field crops and the procurement of irrigation water are closely correlated, and the village and farmers have been surviving on maintaining this relationship.

The Hussaini village is no exception, but due to its geographical environment differing from other villages, securing irrigation water supply was very difficult for it. The village had spent a long time building five irrigation ditches for procuring a stable supply of irrigation water and for drawing water from beneath the moraine deposition, and it had devised a distribution system unique to the village. Nonetheless, this did not surface as a significant problem in the traditional agriculture that cultivated wheat and bean crops, although a fundamental resolution was not found in the geographical environment of the Hussaini village.

However, triggered by the opening of the $\mathrm{KKH}$, the irrigation water supply problem surfaced with the development of the goods/money economy and the change in lifestyle to one that required monetary income. The primary reason for this problem lies in the introduction of cash crop potato cultivation as a means to gain income and the expansion of cropland. Securing a stable yield and quality of potato cultivation in this region required a stable supply of water, but the prevailing geographical condition of the Hussaini village did not allow for an easy fulfilment of this requirement. The Hussaini village received a large sum of funds from the government to draw water from the Gulkin River running from the end of Gulkin glacier; this resolved the problem of shortage by drawing this water to the existing irrigation ditches using steel pipes. Consequently, an ample amount of irrigation water irrigates the potato cropland of the Hussaini village and has resolved the water shortage problem for the time being. In the village, for the sake of stabilising the supply of irrigation water, every farmer is obligated to pay an amount according to the cropland area they benefit from, and using this fund, selected farmers have been exclusively allocated the task of the management and repair of the water intake point, steel pipes, and irrigation ditches. Although some issues are left unresolved, the resolution of the water shortage problem has played a key role in the sustainable development of the Hussaini village. 


\section{Summary}

On the basis of the important perspective obtained from this report, the development of a village that relies on a vulnerable economic infrastructure while confronted with the severe natural environment of the dry mountainous area is not realised by rejecting its conventional agriculture and excessively specialising in single-crop farming of a cash crop. For the sustainable development of a village, it is ultimately necessary to introduce modern agricultural technology and diverse cash crop cultivation based on the proven traditional farming and dependency on the natural environment and regional resources surrounding the village; further, farm management that takes into account productivity and sustainability while harmonising traditional farming and newly introduced technology and crops should be established. Once this is accomplished, in order to improve the regional economy, there is a need to explore a new industry that exploits the rich natural environment and regional resources, for example, ecotourism (Iwata and Watanabe, 2007).

\section{Acknowledgements}

I obtained research funds for my research study from The Grant-in-Aid for Scientific Research (Grant No.17401002, Spokesperson: WATANABE Teiji) and from the College of Humanities and Sciences, Nihon University. During my research, I was under the care of Wakhi people of Hussaini village. I would like to take this opportunity to thank my university and the Wakhi people.

\section{Notes}

1) The Wakhi is a minority mountain tribe that originated in the Wakhan region in northeast Afghanistan. They do not have a written language, but the spoken language of the Wakhi belongs to the Iranian language group of the Indo-European language family, similar to Persian and Tajik. The religion practiced by the Wakhi is Ismailism, a branch of Islam.

2) The AKRSP is an Aga Khan farming village support programme, part of the Aga Khan Development Network. It was established in 1982 in Gilgit, the central city of northern Pakistan, for the primary purpose of the development of the Northern Areas of Pakistan

3 ) The Gojal district, including the Hussaini village, lacks official statistical data, which results in inconsistency in numerical data for each survey or interviewee.

4 ) The method used for preserving potato sets during the frigid winters is important for carrying over potato sets to the next year. In the Hussaini village, the potato sets are preserved in the cropland about 1 to $1.5 \mathrm{~m}$ below ground, but if this preservation is not sufficient, the yield will be affected.

\section{References}

Iwata, S. and Watanabe, T. (2007): A proposal on glacier tourism of Pasu Glacier, Gojal, northern Pakistan. Rikkyo University Bulletin of Studies in Tourism, No.9, 11-26. [in Japanese]

Kreutzmann, H. (1996): Ethnizität im Entwicklungsprozeß. Die Wakhi in Hochasien. Berlin, Dietrich Reimer Verlag.

Mizushima, K. (2006): NGO organization of the Wakhi people in Gojal, Northern Areas of Pakistan-In case study of Hussaini Village - . Proceeding of Institute of Natural Sciences, Nihon University, No. 41, 31-38. [in Japanese]

Mizushima, K. (2008): Irrigation system in Gojal, Northern Areas of Pakistan - In case study of Hussaini Village - . Proceeding of Institute of Natural Sciences, Nihon University, No. 43, 43-53. [in Japanese]

Mizushima, K. (2009): Changing and current situation of cultivation, livestock and the foundation of livelihood in Gojal, Northern Areas of Pakistan - A case study of Shimshal Village - . Proceeding of Institute of Natural Sciences, Nihon University, No. 44, 19-36. [in Japanese]

Ochiai, Y. and Mizushima, K. (2004): Changes in life styles as a result of regional development in Gojal, North Area of Pakistan. Chigakuzashi (Journal of Geography), 113, 312-329. [in Japanese]

Waragai, T. (2008): Physiographical features in upper Hunza region, Karakoram, Northern Pakistan: Preliminary data. Proceeding of The Institute of Natural Sciences Nihon University, 67-75. [in Japanese] 